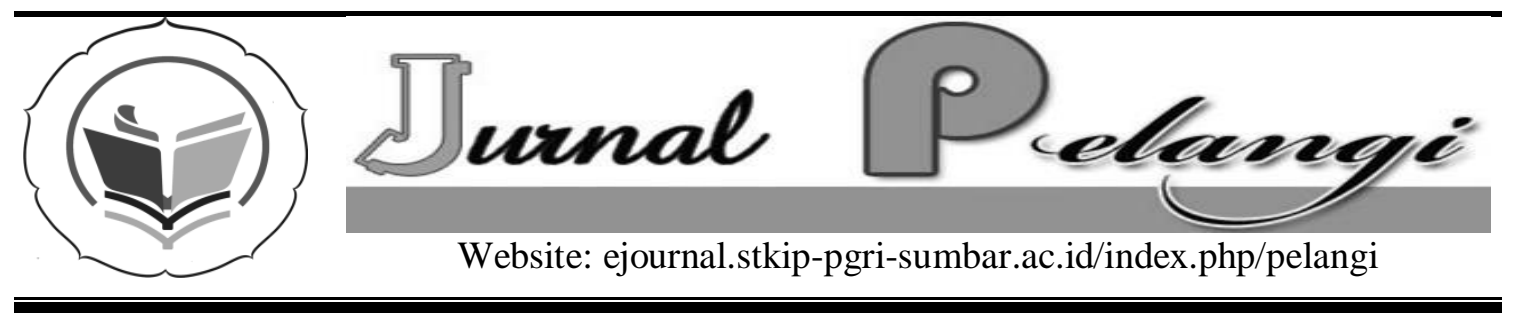

\title{
PENERAPAN MODEL PEMBELAJARAN KOOPERATIF (COOPERATIVE LEARNING) DALAM PENINGKATAN MOTIVASI, AKTIVITAS DAN HASIL BELAJAR SISWA KELAS XI IPS SMA
}

\author{
Wannasri \\ SMA Negeri 1 Palembayan \\ yeni.kurniawati08@gmail.com
}

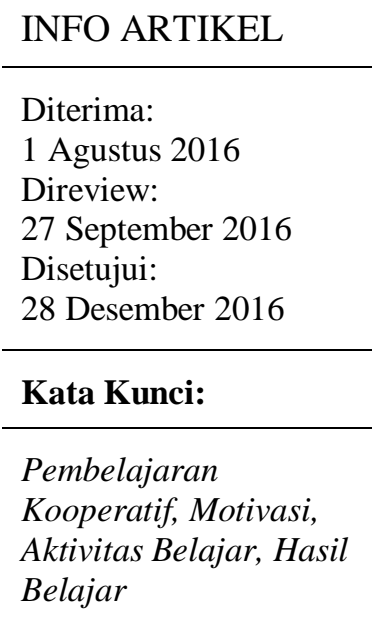

\section{Keywords:}

Cooperative Learning, Motivation, Activity, Learning Achievement

\begin{abstract}
Abstrak
Penelitian ini bertujuan untuk mencari suatu strategi pembelajaran yang efektif dan Efisien dalam meningkatkan motivasi, aktivitas serta peningkatan hasil belajar bagi siswa kelas XI IPS di SMA Negeri 1 Palembayan dengan cara mengaktifkan siswa menggunakan model pembelajaran kooperatif (cooperative learning). Strategi dalam penelitian tindakan kelas ini dilakukan melalui 2 siklus dan pada setiap siklus meliputi kegiatan perencanaan, pelaksanaan, observasi dan refleksi. Sedang untuk mengaktifkan siswa dalam penelitian ini, peneliti menggunakan lembar kerja yang diberikan kepada siswa di tiap kelompok. Subjek pada penelitian tindakan kelas ini adalah siswa kelas XI IPS SMA Negeri 1 Palembayan sedang objeknya adalah pembelajaran materi wawasan lingkungan dan pembangunan berkelanjutan pada mata pelajaran Geografi yang diajarkan dengan cara mengaktifkan siswa dalam kelompok. Dari penelitian yang diadakan dengan meneliti kondisi awal siswa yang diukur dengan alat tes tertulis dan hasil penelitian tindakan kelas dengan 2 siklus terlihat adanya peningkatan hasil yang dicapai siswa dalam menguasai materi wawasan lingkungan dan pembangunan berkelanjutan yang diberikan.
\end{abstract}

\begin{tabular}{l} 
Abstract \\
\hline This study aims to find an effective and Efficient learning \\
strategies in improving motivation, activity and improvement \\
of learning outcomes for students of class XI IPS in SMA \\
Negeri 1 Palembayan by activating students using cooperative \\
learning model. The strategy in this classroom action research \\
is done through 2 cycles and each cycle involves planning, \\
implementation, observation and reflection. Being to enable \\
students in this study, researchers used a spreadsheet given to \\
students in each group. Subjects in this classroom action \\
\hline
\end{tabular}


research is the students of class XI IPS SMA Negeri 1 Palembayan is the object is learning materials environmental insight and sustainable development on Geography subjects are taught by activating students in groups. From research conducted by examining the initial condition of students as measured by written test and classroom action research results with 2 cycles seen the improvement of the results achieved by students in mastering environmental insight materials and sustainable development provided

\section{PENDAHULUAN}

Penelitian tindakan kelas ini dilaksanakan dengan mengambil lokasi di SMA Negeri 1 Palembayan pada bulan Februari sampai dengan Maret tahun 2017 dengan menggunakan 2 siklus.

Subyek dari penelitian tindakan kelas ini adalah siswa kelas XI program IPS yaitu kelas XI IPS1 SMA Negeri 1 Palembayan tahun ajaran 2016 - 2017. Pengambilan subyek penelitian ini didasarkan pada kondisi kelas yang mampu mewakili siswa kelas XI IPS secara keseluruhan. Kelas ini dipilih sebagai objek penelitian dikarenakan peneliti ingin mencari suatu strategi pembelajaran yang efektif untuk meningkatkan penguasaan materi geografi bagi para siswa program IPS dimana dalam pembelajaran kurang menguasai materi dan kurang serius.

$$
\text { Penelitian tindakan kelas }
$$

dilaksanakan dengan tahapan perencanaan, tindakan, observasi, dan evaluasi/refleksi dan disajikan dalam dua siklus, yaitu siklus pertama yang meliputi:

\section{A. Pendahuluan}

Mempersiapkan konsep materi pembelajaran yang akan dicantumkan didalam LKS dan Rencana Pelaksanaan Pembelajaran (RPP) yaitu materi yang terdapat pada KD 3.2) Menganalisis pelestarian lingkungan hidup dalam kaitannya dengan pembangunan berkelanjutan.
B. Langkah utama

1) Guru membagi siswa kedalam kelompok-kelompok

2) Guru menjelaskan tujuan pembelajaran

3) Guru memberikan lembar kerja siswa kepada masing-masing kelompok, mengamati dan mendiskusikan materi sesuai dengan tugasnya secara kelompok

4) Setelah diskusi selesai, ketua kelompok menyampaikan hasil diskusi kelompoknya.

C. Langkah penutup

1) Guru memberikan penilaian kepada kelopok-kelompok siswa melakukan pengamatan dan diskusi itu.

2) Guru bersama siswa menyimpulkan materi yang dipelajari hari itu.

Siklus kedua perencanaannya sama dengan siklus 1 tetapi terdapat revisi setelah adanya pelaksanaan pada siklus 1.

Penelitian ini dipergunakan untuk mencari suatu strategi pembelarjaran yang tepat untuk meningkatkan penguasaan materi geografi secara efektif dan efisien, sehingga arah penelitian ini yaitu meningkatkan motivasi, aktivitas dan peningkatan dalam hasil belajarnya maka untuk pengukuran masalah tersebut peneliti menggunakan alat pengumpul data yang berupa tes tertulis yang berupa soal dan pembahasan.

Data dikumpulkan, kemudian dipetakan dan dianalisis bersama mitra kolabolator sejak penelitian dimulai. 
Selanjutnya dikembangkan selama proses penyusunan laporan. Teknis analisis data yang digunakan adalah metode alur, yaitu reduksi data, penyajian data dan penarikan kesimpulan (Miles \& Huberman, 1989).

Dalam penelitian ini terdapat beberapa aspek yang menjadi fokus untuk diteliti. Aspek-aspek tersebut meliputi: Siswa yaitu a) Keaktifan, b) Motivasi dan c) Hasil Belajar. Guru : a) Meningkatnya motivasi dan aktivitas pembelajaran siswa terutama dalam mempelajari materi Geografi b) Membuat suasana belajar yang menyenangkan c) Meningkatnya hasil belajar siswa.

\section{METODE PENELITIAN}

Penelitian tindakan kelas ini dilaksanakan dengan mengambil lokasi di SMA Negeri 1 Palembayan pada bulan Februari sampai dengan Maret tahun 2017 dengan menggunakan 2 siklus.

Subyek dari penelitian tindakan kelas ini adalah siswa kelas XI program IPS yaitu kelas XI IPS1 SMA Negeri 1 Palembayan tahun ajaran 2016 - 2017. Pengambilan subyek penelitian ini didasarkan pada kondisi kelas yang mampu mewakili siswa kelas XI IPS secara keseluruhan. Kelas ini dipilih sebagai objek penelitian dikarenakan peneliti ingin mencari suatu strategi pembelajaran yang efektif untuk meningkatkan penguasaan materi geografi bagi para siswa program IPS dimana dalam pembelajaran kurang menguasai materi dan kurang serius.

Penelitian tindakan kelas dilaksanakan dengan tahapan perencanaan, tindakan, observasi, dan evaluasi/refleksi dan disajikan dalam dua siklus, yaitu siklus pertama yang meliputi:
A. Pendahuluan

Mempersiapkan konsep materi pembelajaran yang akan dicantumkan didalam LKS dan Rencana Pelaksanaan Pembelajaran (RPP) yaitu materi yang terdapat pada KD 3.2) Menganalisis pelestarian lingkungan hidup dalam kaitannya dengan pembangunan berkelanjutan.

B. Langkah utama

1) Guru membagi siswa kedalam kelompok-kelompok

2) Guru menjelaskan tujuan pembelajaran

3) Guru memberikan lembar kerja siswa kepada masing-masing kelompok, mengamati dan mendiskusikan materi sesuai dengan tugasnya secara kelompok

4) Setelah diskusi selesai, ketua kelompok menyampaikan hasil diskusi kelompoknya.

C. Langkah penutup

1) Guru memberikan penilaian kepada kelopok-kelompok siswa melakukan pengamatan dan diskusi itu.

2) Guru bersama siswa menyimpulkan materi yang dipelajari hari itu.

Siklus kedua perencanaannya sama dengan siklus 1 tetapi terdapat revisi setelah adanya pelaksanaan pada siklus 1.

Penelitian ini dipergunakan untuk mencari suatu strategi pembelarjaran yang tepat untuk meningkatkan penguasaan materi geografi secara efektif dan efisien, sehingga arah penelitian ini yaitu meningkatkan motivasi, aktivitas dan peningkatan dalam hasil belajarnya maka untuk pengukuran masalah tersebut peneliti menggunakan alat pengumpul data yang berupa tes tertulis yang berupa soal dan pembahasan.

Data dikumpulkan, kemudian dipetakan dan dianalisis bersama mitra kolabolator sejak penelitian dimulai. Selanjutnya dikembangkan selama 
proses penyusunan laporan. Teknis analisis data yang digunakan adalah metode alur, yaitu reduksi data, penyajian data dan penarikan kesimpulan (Miles \& Huberman, 1989).

Dalam penelitian ini terdapat beberapa aspek yang menjadi fokus untuk diteliti. Aspek-aspek tersebut meliputi: Siswa: a) Keaktifan, b) Motivasi dan c) Hasil Belajar, Guru : a) Meningkatnya motivasi dan aktivitas pembelajaran siswa terutama dalam mempelajari materi Geografi b) Membuat suasana belajar yang menyenangkan c) Meningkatnya hasil belajar siswa.

\section{HASIL DAN PEMBAHASAN}

\section{Pelaksanaan Siklus Pertama}

Tindakan siklus kesatu dilaksanakan pada awal pertengahan Februari selama dua kali pertemuan. Kegiatan yang dilakukan pada perencanaan tindakan siklus kesatu ini adalah penyusunan persiapan mengajar model pembelajaran kooperatif (cooperatif learning).

Sebelum pelaksanaan tindakan atau siklus pertama berlangsung maka berdasarkan temuan selama pembelajaran geografi terdapat kekurangan dimana kurangnya ketrlibatan siswa dalam pembelajaran, dan siswa menjadi pasif sehingga berpengaruh terhadap hasil belajar yang diharapkan. Hal ini terjadi karena pembelajaran yang dikembangkan satu arah yaitu berpusat pada guru (teacher centered), sedangkan siswa hanya menjadi pendengar dan hanya mencatat apa yang telah disampaikan guru di depan kelas. Kondisi ini membuat siswa menjadi pasif dan motivasi belajar rendah, mereka terlihat mengantuk dan prestasi belajar sangat rendah.

Dalam kondisi demikian maka peneliti mengubah model pembelajaran yaitu dengan menggunakan pembelajaran kooperatif yang diharapkan dapat melibatkan siswa lebih banya dalam pembelajaran. Tahap perencanaan dalam model pembelajaran kooperatif yang pertama dengan membuat rencana pelaksanaan pembelajaran (RPP) untuk KD 3.2 yaitu tentang wawasan lingkungan dan pembangunan berkelanjutan.

Pada tahap pelaksanaan sebelum pembelajaran dimulai guru menjelaskan tujuan pembelajaran dan menjelaskan materi terlebih dahulu secara umum. Setelah selesai kemudian siswa diminta duduk sesuai dengan kelompok yang telah ditentukan, untuk mendiskusikan LKS yang akan diberikan guru pada tiap kelompok dan berdiskusi.

Setelah guru memberi penjelasan siswa tampak mulai bekerja menyelesaikan tugas yang diberikan. Sementara siswa meaksanakan pekerjaan kelompoknya, maka tindakan guru selanjutnya adalah mengawasi jalannya diskusi dan sesekali memberikan arahan bekerja dalam kelompok.

Diskusi berjalan sampai dengan batas waktu yang telah ditentukan, da kemudian guru menutup pembelajaran dengan meminta siswa masing-masing kelompok untuk maju ke depan mempresentasikan hasil diskusinya. Setelah semua kelompok maju, maka tahap akhir pembelajaran adalah membuat kesimpulan.

Hasil observasi yang diperoleh selama siklus satu berlangsung guru maupun siswa belum sepenuhnya sesuai dengan harapan. Hal ini terlihat dari siswa yang belum terlalu antusias dalam diskusi kelompok, dimana kebanyakan siswa dalam tiap kelompok tersebut hanya mengandalkan siswa yang berprestasi saja untuk menjawab soal yang diberikan oleh guru.

Aspek kerja sama juga belum terlihat maksimal, dimana siswa yang pintar kurang membimbing siswa yang kurang dan hanya bertanggung jawab 
pada tugas yang diberikan oleh guru saja sehingga seperti kurang peduli dengan permasalahan yang seharusnya dipecahkan secara bersama-sama. Pada saat diskusi sudah mulai terlihat siswa yang aktif dalam bertanya dan siswa yang menanggapi. Maka secara klasikal semua siswa sudah mulai terbiasa dengan pembelajaran kooperatif dan aktivitas belajarnya mulai mengalami peningkatan. Indikator peningkatan motivasi belajar juga terlihat dari adanya peningkatan nilai rata-rata dalam pengerjaan LKS siswa tiap kelompok selama siklus satu.

Berdasarkan hasil evaluasi dari hasil observasi atau pengamatan selama berlangsung siklus 1 terdapt beberapa hal yang harus diperbaiki untuk siklus kedua dari hasil siklus 1 .

Pada dasarnya langkah-langkah pembelajaran kooperatif sudah melibatkan siswa dalam pembelajaran sehingga tidak lagi bersifat teacher centered. Namun dalam pelaksanaan masih ada beberapa hal yang harus diperbaiki yaitu:

a. Dalam penjelasan materi diawal disarankan lebih banyak memberikan contoh-contoh yang relevan dengan kehidupan seharihari jdai siswa lebih jelas dan lebih termotivasi untuk mengetahui lebih banyak tentag materi yang akan dipelajari.

b. Selama diskusi berlangsung sebaiknya guru lebih intensif memantau siswa sehingga siswa lebih serius lagi dalam memperhatikan temannya yang sedang presentasi.

c. Motivasi siswa sudah mulai meningkat perlu diarahkan untuk semua siswa dengan selalu memberikan reward berupa pujian bahkan nilai tambah bagi siswa yang aktif dalam memberikan pertanyaan atau mengomentari setiap diskusi berlangsung.

d. Kerjasama siswa didalam kelompok juga perlu ditingkatkan lagi dengan cara membuat setiap seorang siswa dapat menjawab satu dari pertaynyaan-pertanyaan yang diberikan oleh guru.

\section{Pelaksanaan Siklus Kedua}

Kegiatan yang dilakukan pada perencanaan tindakan siklus kedua ini adalah penyusunan persiapan mengajar model pembelajaran kooperatif (cooperatif learning) dengan memberikan perhatian lebih pada LKS yang harus diselesaikan oleh siswa dalam bekerjasama yang sudah disesuaikan dengan alokasi waktu. Kemudian pola interaksi yang dilakukan oleh guru diusahakan tidak lagi satu arah dengan metode penyampaian materi yang lebih variatif.

Pada tahap pelaksanaan sebelum pembelajaran dimulai guru mengadakan apersepsi terlebih dahulu, menjelaskan tujuan pembelajaran dan menjelaskan materi terlebih dahulu secara umum. Setelah selesai kemudian siswa diminta duduk sesuai dengan kelompok yang telah ditentukan, untuk mendiskusikan LKS yang akan diberikan guru pada tiap kelompok dan berdiskusi.

Setelah diskusi kelompok selesai, saat presentasi di depan kelas tampak ketua kelompok sudah melaksanakan tugasnya dengan baik yaitu sebelum membacakan hasil diskusinya terlebih dahuul memperkenalkan anggota kelompoknya dan menyebutkan tugas masing-masing anggota. Hal ini menunjukkan bahwa kelompok tersebut telah mampu mengembangkan nilai-nilai demokrasi yang dikehendaki dalam model pembelajaran kooperatif. Tapi masih terkendala oleh waktu tidak bisa seluruh kelompok menampilkan hasil diskusi mereka. Tetapi guru tetap 
melaksanakan kegiatan penutup yaitu menutup pelajaran dengan bersama membuat kesimpulan pelajaran hari itu dan memberikan soal latihan untuk dibuat di rumah.

Kegiatan pembelajaran dengan menggunakan model pembelajaran kooperatif pada tindakan kedua nii sudah cukup baik. Hal-hal yang dianggap kurang baik pada tindakan pertama sudah ada yang diperbaiki sehingga pembelajaran berlangsung kondusif. Dimana guru sudah berusaha menempatkan dirinya sebagai motivator, fasilisator, mediator dan dinamisator dalam proses pembelajaran tersebut sehingga kelemahan yang terdahulu dalam menghandle jalannya diskusi sudah terlaksana dengan baik.

Dalam kegiatan inti, khususnya yang berkenaan dengan aspek-aspek kerjasama, aspek kepemimpinan dan penanaman nilai-nilai demokrasi telah sesuai dengan yang diharapkan walau masih terdapat kelemahannya tapi bisa dimaklumi karena semua masih butuh proses yang lama untuk terbiasa.

Kemudian dalam hal menutup pelajaran, guru telah mampu melaksanakannya dengan baik. Kegiatan ini tentunya sangat penting supaya penguatan tentang materi pembelajaran dapat tersampaikan dengan baik dan siswa lebih mengerti dan memahami materi pelajaran.

Pada akhir siklus kedua guru memberikan ulangan harian untuk KD 3.2 tersebut, dan berdasarkan hasil belajarnya terlihat terjadinya peningkatan hasil belajar secara klasikal walau masih ada siswa yang tidak tuntas.

Hasil penelitian di kelas XI IPS 1 SMA Negeri 1 Palembayan, menunjukkan bahwa rendahnya motivasi dan hasil belajar dapat diatasi salah satunya dengan menggunakan model pembelajaran kooperatif. Berdasarkan hasil penelitian, sistempembelajaran dengan menggunakan model pembelajaran kooperatif dapat meningkatkan efektifitas pembelajaran. Dimana guru sudah melaksanakan semua fase yang diperlukan dalam pembelajaran kooperatif dengan sangat baik. Hal ini terbukti dari beberapa fenomena berikut ini.

\section{Motivasi Belajar}

Berdasarkan hasil penelitian, melalui penggunaan model pembelajaran kooperatif, keseriusan siswa untuk belajar meningkat, yang ditunjukan oleh aktivitas mereka ketika guru menjelaskan dan etika mereka diskusi, dimana mereka berusaha untuk bertanya, menjawab dan menanggapi permasalahan serta semua ikut andil menyelesaikan masalah dalam LKS yang ditugaskan pada setiap kelompok, sehingga jarang ditemukan siswa yang mengantuk seperti ketika mendengarkan ceramah guru.

Pembelajaran dengan menggunakan model pembelajaran kooperatif dapat mengaktifkan siswa sehingga dapat berubah pola teacher centered ke student centered hal ini tidak tidak terlepas dari strategi yang diterapkan baik dalam hal perencanaan, implementasi maupun evaluasi. Dalam proses implementasi terhadap beberapa faktor yang mempengaruhi keberhasilan yaitu perpaduan antara anggota yang heterogen berdasarkan jenis kelami maupun kemampuan akademisnya, alokasi waktu dan sarana yang tersedia dan yang terakhir adalah faktor kemampuan guru yang mampu memposisikan diri sebagai faslitator, motivator dan evaluator.

\section{Hasil Belajar Siswa}

Ditinjau dari aspek prestasi dan kreatifitas siswa maka model pembelajaran kooperatif telah mampu meningkatkan hasil belajar untuk mencapai nilai yang melebihi kriteria 
ketuntasan minimal sehingga secara klasikal siswa di kelas tersebut telah tuntas.

\section{PENUTUP}

Dari hasil dan pembahasan penelitian tindakan kelas yang telah dilaksanakan pada siswa kelas XI program IPS SMA Negeri 1 Palembayan ini, maka dapat ditarik kesimpulan bahwa model pembelajaran kooperatif ini dapat meningkatkan motivasi dan aktivitas siswa dalam belajar Geografi. Keberhasilan ini tercermin dari hasil ulangan harian yang menunjukkan peningkatan hasil belajar dari seswa secara individual maupun secara berkelompok.

\section{UCAPAN TERIMA KASIH}

Terbitnya tulisan ini tidak terlepas dari bantuan berbagai pihak, untuk itu penulis ucapkan terima kasih kepada UP3M STKIP PGRI Sumatera Barat sebagai penyandang dana dan pengelola jurnal Pelangi yang telah memberikan saran dan revisi dalam penulisan artikel ini.

\section{DAFTAR PUSTAKA}

A.M. Sardiman. 2011. Interaksi dan Motivasi Belajar Mengajar. Jakarta: Rajawali.
Daniel Muijs dan David Reynolds 2008. EffectiveTteaching Teori dan Aplikasi (Edisi ke -2 ) Yogyakarta : Pustaka Pelajar.

Hanafiah, Nanang \& Cucu Suhana. 2010. Konsep Strategi Pembelajaran. Bandung: Refika Aditama

Nana Sudjana. 1995. Penilaian Hasil Proses Belajar Mengajar. Bandung : PT Remaja Rosdakarya.

Nina Salmita. 2015. Melaksanakan Penelitian Tindakan Kelas (PTK) Dengan Cara Yang Mudah( Untuk guru mata pelajaran - guru kelas dan guru BK ). Bogor : PT Grha Cipta Media

Gagne, Robert M and Leslie J. Briggs, 1978. Principles of Instructional Design. $2^{\text {nd }} E d$, New York : Holt Rinehart and Winstons.

Program Pasca Sarjana UNP. 2004. Buku Panduan Penulisan Tesis dan Disertasi. Padang. Pasca Sarjana.

http://ainamulyana.blogspot.com/2012/0 2/motivasi-belajar.html, diakses pada tanggal 9 Februari 2017 